\title{
Xanthine Oxidase Inhibitory Activity of a Plectranthus saccatus aqueous extract
}

\author{
Ação inibidora da xantina oxidase de um extracto aquoso de Plectranthus saccatus \\ Francisco Caldeira, João Costa ${ }^{1,2}$, Patrícia Rijo ${ }^{1,2}$, Nuno Saraiva ${ }^{1^{*}}$, Ana Fernandes ${ }^{1^{*}}$ \\ ${ }^{1}$ CBiOS, Universidade Lusófona Research Center for Biosciences \& Health Technologies, Lisboa, Portugal \\ 2 iMed.ULisboa - Research Institute for Medicines, Faculty of Pharmacy, University of Lisbon, Lisboa, Portugal \\ Email: ana.fernandes@ulusofona.pt \\ * Shared senior authorship
}

\begin{abstract}
Gout is a disease with high prevalence in developed countries, resulting from the deposition of uric acid crystals in various locations, particularly at the joints. The pharmacotherapeutic approach to chronic gout essentially consists of administration of uric acid-lowering agents. The main mechanism of action of these agents is the inhibition of xanthine oxidase (XO), the enzyme responsible for the formation of uric acid. The therapeutic alternatives available for this purpose are limited, thus justifying the interest of the discovery of potential new uric acidlowering drugs. In this regard, an aqueous extract of the plant Plectranthus saccatus has been studied for its ability to inhibit XO. The composition of the extract was determined by HPLC and rosmarinic acid was identified as the major constituent. Both the extract and rosmarinic acid have demonstrated the ability to inhibit the production of uric acid by interfering with XO activity. The results obtained herein support the continuation of the study of their uric acid-lowering properties in cell-based and in vivo models to further explore their potential in gout therapy.
\end{abstract}

Key-words: Plectranthus saccatus, rosmarinic acid, xanthine oxidase, uric acid, gout

\section{Resumo}

A gota é uma patologia com elevada prevalência nos países desenvolvidos, que resulta da deposição de cristais de ácido úrico em várias localizações, sobretudo ao nível das articulações. A abordagem farmacoterapêutica da gota crónica consiste essencialmente na administração de agentes hipouricemiantes, i.e., fármacos que permitem reduzir os níveis séricos de ácido úrico. Estes agentes apresentam como principal mecanismo de ação a inibição da xantina oxidase (XO), a enzima responsável pela formação de ácido úrico. As alternativas terapêuticas disponíveis para este fim são limitadas, o que justifica o interesse da descoberta de potenciais novos fármacos hipouricemiantes. Neste âmbito, foi estudado um extrato aquoso da planta Plectranthus saccatus, relativamente à capacidade de inibição da XO. A composição do extrato foi determinada por HPLC, tendo-se identificado o ácido rosmarínico como constituinte maioritário. Tanto o extrato como o ácido rosmarínico demonstraram a capacidade de inibir a produção de ácido úrico por interferirem com a atividade da XO. Os resultados obtidos sustentam a continuação do estudo das suas propriedades hipouricemiantes em modelos celulares e in vivo, de modo a explorar mais aprofundadamente as suas potencialidades na terapêutica da gota.

Palavras-chave: Plectranthus saccatus, ácido rosmarínico, xantina oxidase, ácido úrico, gota 


\section{Introduction}

Gout is an inflammatory arthropathy caused by a deficient metabolism of uric acid / urate (UA), which may be associated with an excessive synthesis and / or an impaired renal clearance. This leads to an excess of UA in the blood, called hyperuricemia. The limited solubility of urate in blood leads to the precipitation of monosodium urate crystals (MSU) in various locations of the body such as joints, cartilage, kidney, subcutaneous tissues and soft tissues. The deposition of MSU crystals is more common in peripheral joints, especially in the first metatarsal-phalangeal joint, that is, the big toe. The deposition of crystals in the joints is responsible for the symptoms of the acute attacks of gout, which are characterized by an inflammatory process associated with severe joint pain, swelling and erythema. If not treated or prevented, hyperuricemia may lead to a chronic deposition of MSU crystals associated with inflammation, thus resulting in multiple acute attacks followed by chronic pain, joint destruction and formation of gouty tophi (1-4). Gout can be idiopathic or from familial origin, and is closely related with diet, particularly with the intake of foods that are sources of purines, such as meat, seafood or beer. Purines result from proteins and are degraded to hypoxanthine. Through the action of xanthine oxidase (XO), hypoxanthine will be oxidized into xanthine, and then $\mathrm{XO}$ oxidizes xanthine to uric acid (2, 5; Fig. 1).

\section{Introdução}

A Gota é uma artropatia inflamatória provocada por um deficiente metabolismo do ácido úrico / urato (AU), que pode estar relacionado com uma síntese excessiva e/ou com uma deficiente eliminação renal, levando a que ocorra um excesso de AU no sangue, denominado de hiperuricemia. A limitada solubilidade do urato no sangue leva à precipitação de cristais de urato monossódico (UMS) em diversos locais do corpo humano tais como articulações, cartilagens, rins, tecidos subcutâneos e tecidos moles. A deposição dos cristais de UMS é mais comum nas articulações periféricas, sobretudo na primeira articulação metatarso-falângica, que se encontra no dedo grande do pé. A deposição de cristais nas articulações é responsável pela sintomatologia do ataque agudo de gota, que se caracteriza por um processo inflamatório associado a dor articular intensa, edema e eritema. Quando a hiperuricemia não é tratada ou prevenida, pode levar a uma deposição crónica de cristais de UMS com inflamação associada, resultando assim em múltiplos ataques agudos, seguidos por dor crónica, destruição de articulações e formação de tofos gotosos (1-4). A gota pode ser de origem idiopática ou familiar, e está intimamente relacionada com a dieta alimentar, nomeadamente com a ingestão de alimentos que constituem fontes de purinas, tais como carnes vermelhas, marisco ou cerveja. As purinas resultam das proteínas e vão ser degradadas a hipoxantina. Esta, através da ação da Xantina Oxidase (XO) vai oxidar a hipoxantina em xantina e, posteriormente, a XO oxida a xantina a ácido úrico $(2,5$; Fig. 1$)$.
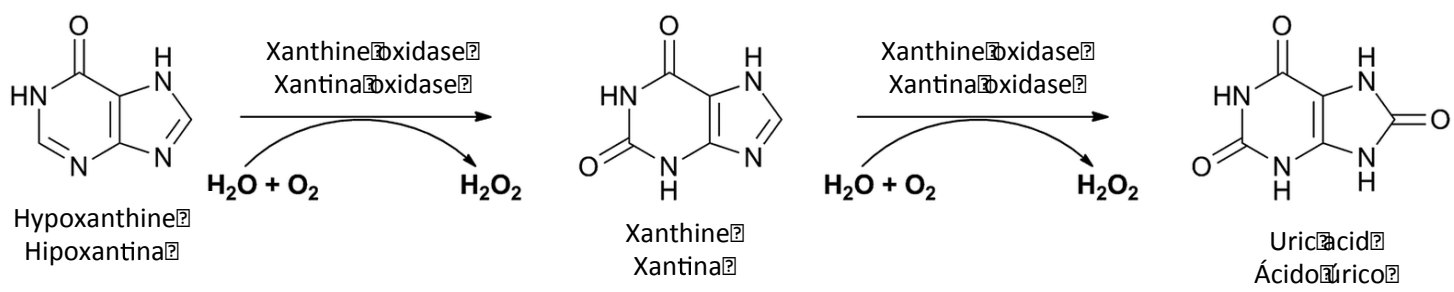

Figure. 1/ Figura 1 - Uric acid production by the enzymatic activity of xanthine oxidase

Produção de ácido úrico pela atividade enzimática da xantina oxidase 
The first therapeutic goal in an acute attack of gout is the rapid pain relief and inhibition of inflammation. For this purpose, non-steroidal anti-inflammatory drugs or colchicine may be used. In the long term, the therapeutic goal is to prevent further gout attacks, avoid urate precipitation, and remove tophi and block joint destruction. To reach these aims, it is essential to consistently reduce the urate levels. According to the recommendations of the American College of Rheumatology (ACR) and the guidelines of the European League Against Rheumatism (EULAR), the recommended level of seric urate should be equal or lower than $6 \mathrm{mg} / \mathrm{dL}$, with further decrease to less than $5 \mathrm{mg} / \mathrm{dL}$ for the overall improvement of symptoms. The reduction of urate is achieved via administration of uric acid-lowering agents, which act by inhibiting the XO enzyme $(1,6,7)$. The drug most used for this purpose is allopurinol. The FDA approved this drug in 1965 and for decades it had been the only agent available as a uric acid-lowering medication (8). It is an hydroxypyrazole pyrimidine, which is a purine analogue and an isomer of hypoxanthine. By the action of $\mathrm{XO}$, allopurinol is metabolized in oxypurinol, its major metabolite. Both allopurinol and oxypurinol decrease the production of UA by competitively inhibiting the activity of XO (Fig. 1). The action of allopurinol leads to a decrease in serum uric acid and in uraturia. Allopurinol is generally well tolerated, although approximately $2 \%$ of patients suffer from allopurinol hypersensitivity syndrome. This is a serious reaction, potentially fatal, with a mortality rate of $20-30 \%$. The manifestations of this syndrome include maculopapular rash, fever, eosinophilia and severe manifestations, such as toxic epidermal necrolysis, acute vasculitis and marked abnormalities of liver and kidney function. Patients with renal impairment or concomitant treatment with diuretics have a higher risk of developing this syndrome $(9,10)$. Febuxostat, a nonpurine analogue that inhibits $\mathrm{XO}$, was approved by the European Medicines Agency (EMA) in 2008 and by the FDA in 2009. This drug has demonstrated potency and efficacy. Furthermore, since it undergoes hepatic metabolism, no dose adjustment is required in the case of renal impairment $(8,9,11,12)$. Although febuxostat was recently authorized in Portugal, this drug is not yet marketed in our country.

The scarce number of uric acid-lowering medications available for the prophylaxis of gout justifies the need to investigate new therapeutic alternatives. In this regard, the present study evaluated the ability of an extract of the plant Plectranthus saccatus (Fig. 2) to inhibit XO. The Plectranthus plants, with over 350 known subspecies, are part of the mint family (Laminacea) and are
O primeiro objetivo terapêtico no ataque agudo de gota é o alívio rápido da dor e inibição da inflamação. Para este fim, podem utilizar-se antinflamatórios não esteroides ou colquicina. A longo prazo, o objetivo terapêutico é evitar novos ataques, impedir a precipitação de urato, remover os depósitos tofáceos e evitar a destruição articular. Para este fim, é fundamental reduzir os níveis de urato de forma consistente. De acordo com recomendações do American College of Rheumatology (ACR) e das guidelines da European League Against Rheumatism (EULAR), o nível recomendado de urato sérico deve ser menor ou igual que $6 \mathrm{mg} / \mathrm{dL}$ com posterior decréscimo para menos de $5 \mathrm{mg} / \mathrm{dL}$ para a melhoria global dos sintomas. A diminuição da produção de urato consegue-se pela administração de agentes hipouricemiantes, os quais atuam por inibição da enzima XO $(1,6,7)$.

O fármaco mais utilizado para este fim é o alopurinol. Este fármaco foi aprovado pela FDA em 1965 e foi, durante décadas, o único agente hipouricemiante disponível (8). Trata-se de uma hidroxipirazolopirimidina, que é um análogo das purinas e isómero da hipoxantina. $\mathrm{O}$ alopurinol, ao ser metabolizado pela $\mathrm{XO}$, passa a Oxipurinol, o seu principal metabolito. O alopurinol e o oxipurinol diminuem a produção de AU por inibição competitiva da ação da XO (Fig. 1).

Sob a ação do alopurinol observa-se uma diminuição da uricemia e da uratúria. O alopurinol é geralmente bem tolerado, apesar de cerca de $2 \%$ dos doentes sofrerem de síndrome de hipersensibilidade ao alopurinol, uma reacção grave, potencialmente letal, com uma taxa de mortalidade de 20-30\%. O exantema maculopapular, a febre, a eosinofilia e manifestações mais graves, como a necrólise epidérmica toxica, a vasculite aguda e alterações acentuadas das funções hepática e renal, são manifestações desta síndrome. Os doentes com insuficiência renal prévia ou em tratamento simultâneo com diuréticos têm risco acrescido de desenvolver esta síndrome $(9,10)$. Recentemente foi aprovado o febuxostate, um inibidor da XO não-análogo de purina, pela Agência Europeia de Medicamentos (EMA) em 2008 e pela FDA em 2009. Este fármaco tem demonstrado potência e eficácia e, dado que sofre metabolização hepática, não requer ajuste à função renal $(8,9,11,12)$. Apesar de ter sido recentemente autorizado em Portugal, o febuxostate ainda não se encontra comercializado no nosso país.

A escassez de agentes hipouricemiantes disponíveis para profilaxia da gota justifica a necessidade de investigar novas alternativas terapêuticas. Assim, no sentido de contribuir para o desenvolvimento de potenciais novos fármacos hipourecemiantes, neste trabalho avaliou- 
widespread in Africa, Madagascar, India, Australia and some islands in the Pacific. This genus is often cited for its medicinal properties and is traditionally used to treat gastro-intestinal, respiratory, infectious (such as malaria) or skin disorders (14). Several components of plants from the Plectranthus genus have been isolated and identified and have shown to have different pharmacological activities including antimicrobial (15), antitumor (16) and antioxidant activities (17). In the present work, the uric acid-lowering properties of an aqueous extract of Plectranthus saccatus plant, as well as of its major constituent, were studied. The present work constitutes therefore a preliminary approach for the study of a possible new therapeutic application of this plant in the treatment of gout. -se o potencial inibitório da XO de um extrato da planta Plectranthus saccatus (Fig. 2). As plantas Plectranthus, com mais de 350 subespécies conhecidas, fazem parte da família da Menta (Laminacea) e encontram-se em África, Madagáscar, Índia, Austrália e algumas ilhas do Pacifico. Este género é frequentemente citado pelas suas propriedades medicinais, sendo usado tradicionalmente para tratar patologias gasto-intestinais, respiratórias, infecciosas (tais como malária) ou cutâneas (14). Vários componentes de plantas do género Plectranthus foram já isolados e identificados, e revelaram possuir diferentes atividades farmacológicas incluindo ação antimicrobiana (15), antitumoral (16) e antioxidante (17). Neste trabalho foi realizado um estudo in vitro com o objetivo de explorar a atividade hipouricemiante de um extrato aquoso da planta Plectranthus saccatus e do seu constituinte maioritário, constituindo este trabalho uma abordagem preliminar ao estudo de uma eventual nova aplicação terapêutica desta planta no tratamento da gota.

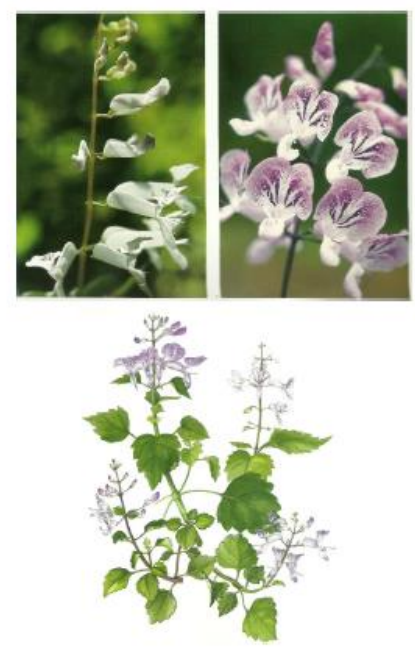

Figure 2/ Figura 2 - Plectranthus saccatus Benth (13) 


\section{Maerials and Methods}

\section{Chemicals}

Xanthine, xanthine oxidase (XO) (E.C.1.1.3.22), allopurinol and rosmarinic acid were obtained from Sigma-Aldrich.

\section{Plant material}

P. saccatus species was provided by the Faculty of Pharmacy of the University of Lisbon (cultivated at the Instituto Superior de Agronomia from seeds provided by the National Botanic Garden, Kirstenbosch, Claremont, South Africa) and the voucher herbarium specimen of P. saccatus (LISI 835/2007) was deposited in the Herbarium João de Carvalho e Vasconcellos of the Instituto Superior de Agronomia, Lisbon (LISI). Plant leaves were dried and cut into small pieces before each extraction method.

\section{Extract preparation}

As previously described (18), the P. saccatus aqueous extract was prepared using a microwave method. The dried plant material $(10 \mathrm{~g})$ was extracted using $100 \mathrm{~mL}$ of distilled water and then filtered through Whatman paper no 5 paper (Whatman, Inc., Clifton, New Jersey, USA).

\section{High-Performance Liquid Chromatography (HPLC) analysis}

The HPLC analysis was carried out as previously described (18) in a Liquid Chromatograph Agilent Technologies 1200 Infinity Series LC System equipped with diode array detector (DAD), using a ChemStation Software and a LiChrospher $100 \mathrm{RP}-18(5 \mu \mathrm{m})$ column from Merck (Darmstadt, Germany). All analyses were performed in triplicate.

\section{Xanthine oxidase inhibition assay}

Xanthine oxidase converts xanthine to uric acid, which has a maximum absorbance at $293 \mathrm{~nm}$. The production of uric acid can thus be monitored by UV spectrophotometry. The protocol used to evaluate the activity of $\mathrm{XO}$ was adapted from Fernandes et al (19). The reaction system (final volume $=1 \mathrm{~mL}$ ) was composed of xanthine $(0.25 \mathrm{mM})$ and the sample under study, in sodium phosphate buffer $0.1 \mathrm{M}, \mathrm{pH} 7.8$. The enzymatic reaction was initiated by the addition of $\mathrm{XO}$ (final concentration $=6 \mathrm{mU} / \mathrm{mL}$ ) and carried out at $25{ }^{\circ} \mathrm{C}$. The production of uric acid was evaluated by measuring the increase in absorbance at $293 \mathrm{~nm}$ at 5 second intervals over $3 \mathrm{~min}-$ utes in a Thermo Evolution 300 UV-vis spectrophotom-

\section{Materiais e Métodos}

\section{Compostos utilizados}

A xantina, a xantina oxidase (XO) (E.C.1.1.3.22), o alopurinol e o ácido rosmarínico foram adquiridos à Sigma-Aldrich.

Material vegetal

A espécie P. saccatus é proveniente da Faculdade de Farmácia da Universidade de Lisboa (cultivada no Instituto Superior de Agronomia a partir de sementes provenientes do National Botanic Garden, Kirstenbosch, Claremont, África do Sul) e foi depositado um voucher herbarium specimen de $P$. saccatus (LISI 835/2007) no Herbário João de Carvalho e Vasconcellos do Instituto Superior de Agronomia, Lisboa (LISI). As folhas da planta forma secas e cortadas em pequenas porções antes do método de extração.

\section{Preparação do Extracto}

Como descrito anteriormente (18) o extracto aquoso de P. saccatus foi preparado através de um método de extração de micro-ondas. O material vegetal seco (10 g) foi extraido com $100 \mathrm{~mL}$ de água destilada e posteriormente filtrado em papel Whatman no 5 (Whatman, Inc., Clifton, New Jersey, USA).

\section{Análise por Cromatografia líquida de alta performance (HPLC)}

A análise por HPLC foi realizada como descrito anteriormente (18) num Cromatógrafo Líquido Technologies 1200 Infinity Series LC System equipado com um detector de foto-diodos (DAD), com um Software ChemStation e uma coluna LiChrospher 100 RP-18 (5 $\mu \mathrm{m})$ da Merck (Darmstadt, Germany). Todas as análises foram efetuadas em triplicado.

\section{Ensaio de inibição da xantina oxidase}

A xantina oxidase converte a xantina em ácido úrico, o qual tem um máximo de absorvância a $293 \mathrm{~nm}$. A produção de ácido úrico pode assim ser monitorizada por espectrofotometria UV. O protocolo utilizado para avaliar a atividade da XO foi adaptado de Fernandes et al (19). O sistema reacional (volume final $=1 \mathrm{~mL}$ ) foi constituído por xantina $(0,25 \mathrm{mM})$ e a amostra em estudo, em tampão fosfato de sódio $0,1 \mathrm{M}$ a pH 7,8. A reação enzimática foi iniciada pela adição de XO (concentração final $=6 \mathrm{mU} / \mathrm{mL}$ ) e realizou-se à temperatura de $25^{\circ} \mathrm{C}$. A produção de ácido úrico foi avaliada medindo o aumento de absorvância a $293 \mathrm{~nm}$ de $5 \mathrm{em}$ 5 segundos, durante 3 minutos, num espectrofotómetro 
eter. Each assay was done in duplicate. The influence of $P$. sacattus extract on $\mathrm{XO}$ activity was assessed using seven concentrations of the extract, ranging from 50 to $1000 \mu \mathrm{g} / \mathrm{mL}$. The rosmarinic acid was evaluated using five concentrations between 100 and $300 \mu \mathrm{M}$ (36 and $108 \mu \mathrm{g} / \mathrm{mL}$ ). The anti-gout drug allopurinol (10 and 20 $\mu \mathrm{g} / \mathrm{mL}$ ) was used as positive control.

Each concentration generated an Abs vs time graph, from which the slope was calculated. The percentage of XO inhibition for each concentration was determined using the formula:

$$
\left[100 \text { - }\left(\text { slope }_{\text {sample }} / \text { slope }_{\text {negative control }}\right) * 100\right]
$$

The $\mathrm{IC}_{50}$ values of the extract and of rosmarinic acid, i.e. the concentration which inhibits by $50 \%$ the activity of $\mathrm{XO}$, was calculated using a linear regression from the plot of the $\% \mathrm{XO}$ inhibition as a function of sample concentration.

\section{Results}

\section{Identification of the major components of the extract}

The phytochemical analysis of the aqueous P. saccatus extract was performed by HPLC and revealed as the main component the rosmarinic acid $(163.62 \mu \mathrm{M}$; Fig. $3)$. Moreover, caffeic and chlorogenic acids were also detected.
Thermo Fisher Evolution 300 UV-vis. Cada ensaio foi feito em duplicado. A influência do extrato de $P$. sacattus na atividade da XO foi avaliada para 7 concentrações do extrato, variando entre 50 e $1000 \mu \mathrm{g} / \mathrm{mL}$. O ácido rosmarínico foi avaliado em 5 concentrações, entre 100 e $300 \mu \mathrm{M}$ ( 36 e $108 \mu \mathrm{g} / \mathrm{mL}$ ). Como controlo positivo utilizou-se o fármaco anti-gotoso alopurinol (10 e $20 \mu \mathrm{g} / \mathrm{mL}$ ). Cada concentração testada originou uma reta Abs vs tempo, da qual foi calculado o declive. A percentagem de inibição da XO para cada concentração foi calculada pela fórmula:

$$
\left[100-\left(\text { declive }_{\text {amostra }} / \text { declive } e_{\text {controlo negativo }}\right) * 100\right]
$$

$\mathrm{O}$ valor de $\mathrm{IC}_{50}$ do extrato e do ácido rosmarínico, ou seja, a concentração que inibe em $50 \%$ a atividade da $\mathrm{XO}$, foi calculada através da regressão linear da representação gráfica da \% de inibição da XO em função da concentração da amostra.

\section{Resultados}

Identificação dos principais componentes do extracto

A análise fitoquímica do extracto aquoso de $P$. saccatus foi realizada por HPLC e revelou como componente principal o ácido rosmarínico $(163,62 \mu \mathrm{M}$; Fig. 3). Além disso, também foram detectados os ácidos clorogénico e cafeíco.

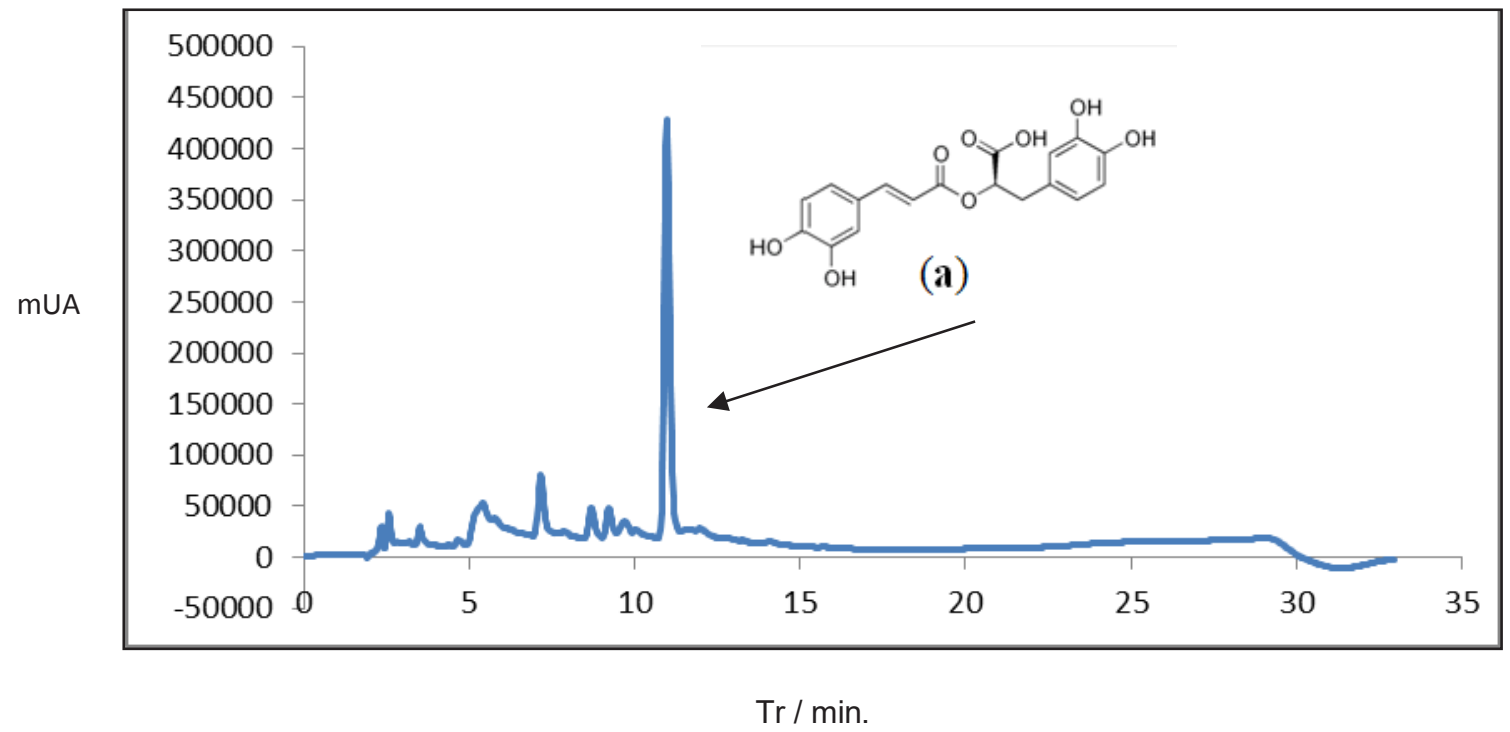

Figure 3/ Figura 3 - Chromatogram of $\mathrm{P}$. saccatus extract ( $5 \mathrm{mg} / \mathrm{mL}$ ) obtained by the microwave method (at $270 \mathrm{~nm}$ ). (a) Rosmarinic acid structure.

Cromatograma do extrato de P. saccatus $(5 \mathrm{mg} / \mathrm{mL})$ obtido pelo método de extração de microondas method (a $270 \mathrm{~nm}$ ). (a) Estrutura do ácido rosmarínico 


\section{Assay validation}

The addition of XO enzyme to the reaction system, composed of Xanthine substrate in phosphate buffer (negative control), led to a time-dependent increase in absorbance at $293 \mathrm{~nm}$, corresponding to an increase in uric acid production (Fig. 4A). This increase confirms the enzymatic activity of XO in the experimental conditions used. To validate the assay, allopurinol was used as a positive control, since this drug is a reference uric acid-lowering agent. Allopurinol inhibited the activity of XO in $83.7 \%$ at the concentration of $10 \mu \mathrm{g} / \mathrm{mL}$ and in $100 \%$ for the concentration of $20 \mu \mathrm{g} / \mathrm{mL}$ (Fig. 4B). The results of these controls allowed us to validate the assay.

\section{Validação do ensaio}

A adição da enzima $\mathrm{XO}$ ao sistema reacional composto pelo substrato Xantina em tampão fosfato (controlo negativo) levou a um aumento da absorvância a $293 \mathrm{~nm}$ ao longo do tempo, correspondendo a um aumento da produção de AU (Fig. 4A). Este aumento confirma a atividade enzimática da XO nas condições experimentais utilizadas.

Para validação do ensaio, utilizou-se o alopurinol como controlo positivo, uma vez que este é o fármaco hipouricemiante de referência. Verificou-se que o alopurinol inibiu a atividade da $\mathrm{XO}$ em $83,7 \%$ para a concentração de $10 \mu \mathrm{g} / \mathrm{mL}$ e em $100 \%$ para a concentração de 20 $\mu \mathrm{g} / \mathrm{mL}$ (Fig. 4B). Os resultados destes controlos permitiram a validação do ensaio.
A

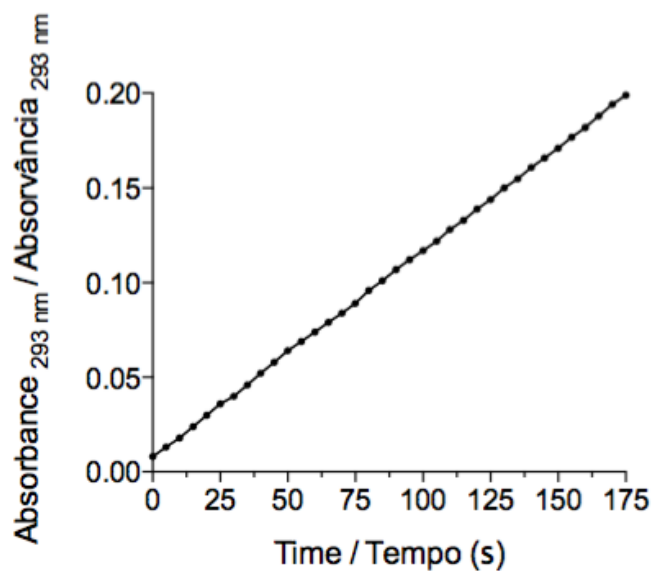

B

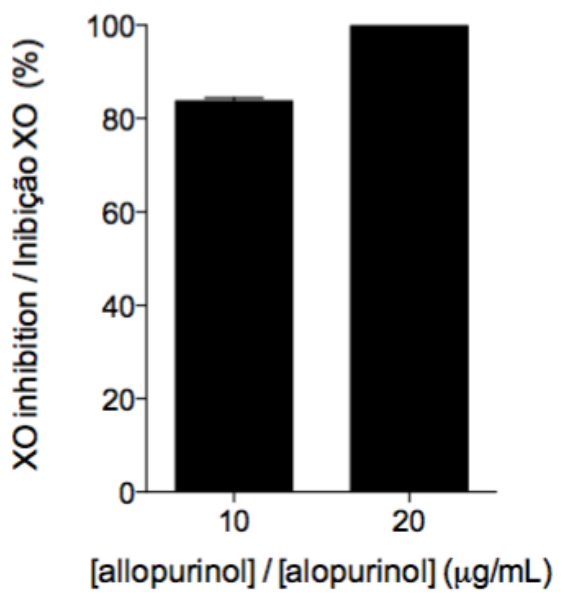

Figure 4/ Figura 4-Validation of the xanthine oxidase (XO) inhibition assay. (A) Uric acid production by the xanthine- xanthine oxidase system. (B) Inhibitory activity of allopurinol towards XO.

Validação do ensaio de inibição da enzima xantina oxidase (XO). (A) Produção de ácido úrico pelo sistema xantina-xantina oxidase. (B) Atividade inibitória do alopurinol sobre a XO. 


\section{P. saccatus extract inhibits $X O$}

The results from the study of the impact of $P$. saccatus extract on XO activity are shown in Figure 5. As can be observed, the P. saccatus extract inhibited XO activity in a concentration-dependent way. The highest concentrations studied $(750 \mu \mathrm{g} / \mathrm{mL}$ and $1000 \mu \mathrm{g} / \mathrm{mL})$ completely inhibited the production of uric acid by the xanthine-XO system. The $\mathrm{IC}_{50}$ value calculated for this extract was $407 \mu \mathrm{g} / \mathrm{mL}$.

\section{Rosmarinic acid inhibits $X O$}

As rosmarinic acid has been identified as the major constituent of $P$. saccatus extract, we also evaluated the effect of this compound on the activity of XO. The results are shown in Figure 6. In this case, an effective and concentration-dependent inhibition of $\mathrm{XO}$ was also observed, with an $\mathrm{IC}_{50}$ value of $76.3 \mu \mathrm{g} / \mathrm{mL}$.
$O$ extrato de P. saccatus inibe a XO

Os resultados do estudo do impacto do extrato de P.saccatus na atividade da XO são apresentados na Figura 5. Como se pode observar, o extrato de P.saccatus apresenta uma atividade inibitória da XO concentração-dependente. As concentrações mais elevadas estudadas $(750 \mu \mathrm{g} / \mathrm{mL}$ e $1000 \mu \mathrm{g} / \mathrm{mL})$ demonstraram inibir totalmente a produção de ácido úrico pelo sistema xantina-XO. $\mathrm{O}$ valor de $\mathrm{IC}_{50}$ calculado para este extrato foi de $407 \mu \mathrm{g} / \mathrm{mL}$.

\section{$O$ ácido rosmarínico inibe a $X O$}

Como o ácido rosmarínico foi identificado como sendo o constituinte maioritário do extrato de P.saccatus, avaliou-se também o efeito deste composto na atividade da XO. Os resultados obtidos apresentam-se na Figura 6. Também neste caso se observou uma inibição da XO eficaz e dependente da concentração, tendo-se obtido um valor de $\mathrm{IC}_{50}$ de $76,3 \mu \mathrm{g} / \mathrm{mL}$.

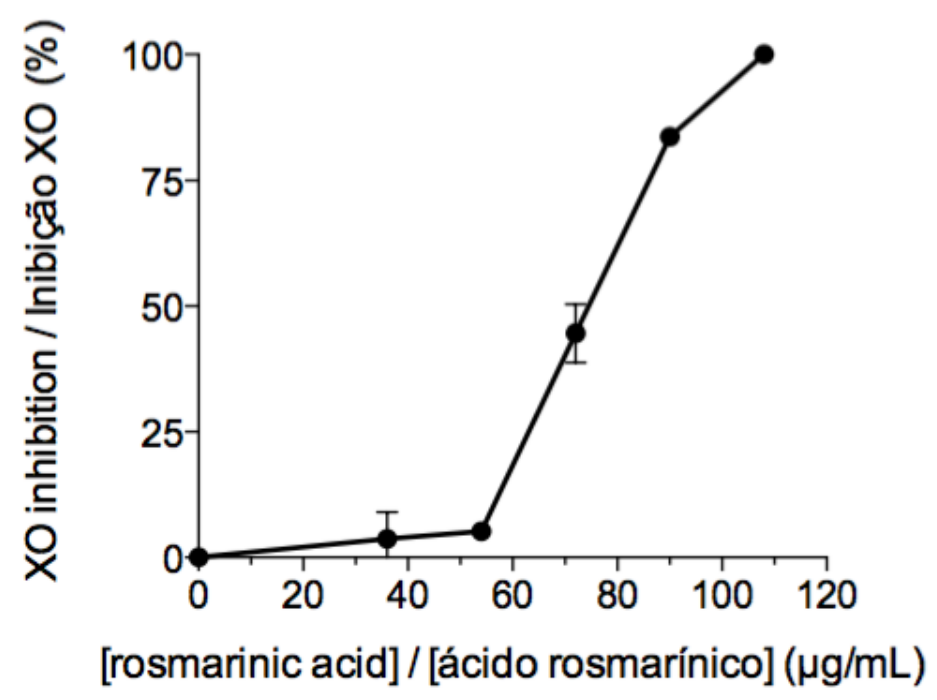

Figure 5/ Figura 5 - Effect of P. saccatus extract on the inhibition of xanthine oxidase (XO) enzymatic activity.

Efeito do extrato de P. saccatus na inibição da atividade enzimática da xantina oxidase 


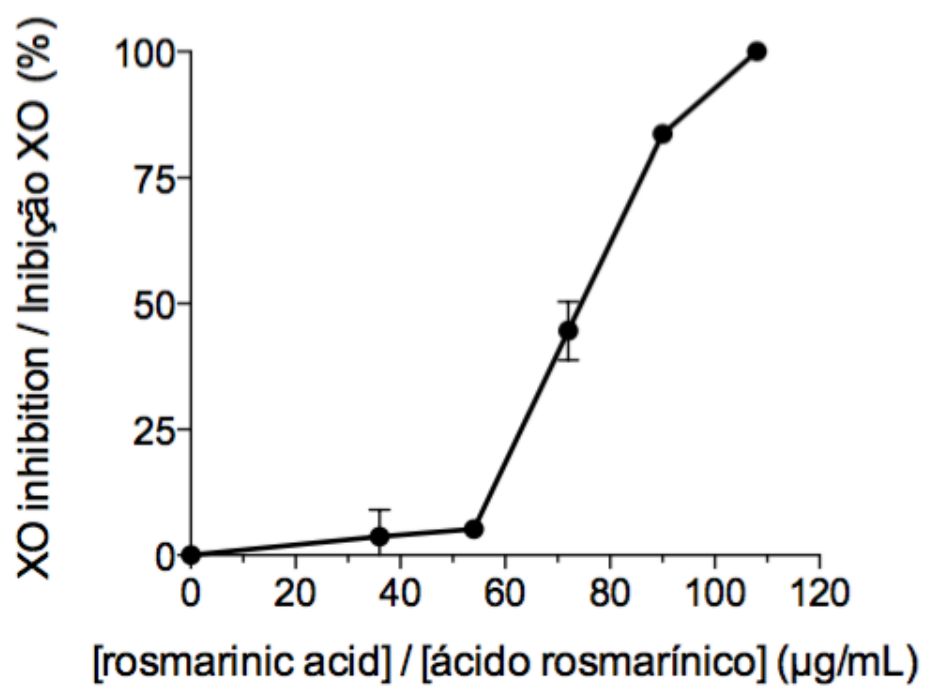

Figure 6/ Figura 6 - Effect of rosmarinic acid on the inhibition of xanthine oxidase (XO) enzymatic activity.

Efeito do ácido rosmarínico na inibição da atividade enzimática da xantina oxidase

\section{Discussion}

Gout is a disease with a high prevalence worldwide, especially in developed countries (4). However, the therapeutic alternatives for this pathology are limited, particularly regarding drugs with uric acid-lowering properties. The search for new XO inhibitors, with less side effects and higher potency, is therefore essential not only for treating gout but also to combat other disorders associated with the activity of XO.

Plants are considered a major source of potential new drugs due to the large number of bioactive compounds that they usually contain. In this regard, this study investigated for the first time the effect of an extract obtained from P. saccatus, a plant used in traditional medicine, on the XO activity and, consequently, on the production of uric acid. Our results show that the $P$. saccatus extract studied effectively inhibited the $\mathrm{XO}$ activity, with a low $\mathrm{IC}_{50}$ value, preventing the in vitro formation of uric acid.

In order to justify the activity found for the extract, it is essential to know its composition. Studies performed by HPLC demonstrated that this sample consists mainly of phenolic compounds such as rosmarinic acid, which is the major component, caffeic acid and chlorogenic acid. Since rosmarinic acid is the major constituent, we evaluated its effect on the activity of XO enzyme. Rosmarinic acid was shown to effectively inhibit this enzyme. This result is in agreement with previously

\section{Discussão}

A gota é uma patologia com elevada prevalência em todo mundo, sobretudo nos países desenvolvidos (4). No entanto, as alternativas terapêuticas para estas patologias são limitadas, sobretudo no que diz respeito a fármacos com propriedades hipouricemiantes. A procura de novos agentes inibidores da $\mathrm{XO}$, com menos efeitos secundários e com maior potência, torna-se assim essencial, não só para o tratamento da gota mas também para o combate de outras patologias associadas à atividade da XO.

Pelo elevado número de compostos bioativos que possuem, as plantas constituem uma fonte muito importante de potenciais novos fármacos. Neste sentido, foi investigada pela primeira vez a ação de um extrato obtido da planta $P$. saccatus, usada em medicina tradicional, sobre a atividade da $\mathrm{XO}$ e, consequentemente, sobre a produção de ácido úrico. Os resultados obtidos demonstram que, in vitro, o extrato de $P$. saccatus estudado inibe eficazmente a XO, com um baixo valor de $\mathrm{IC}_{50}$, impedindo a formação de ácido úrico.

Com o objetivo de tentar justificar este atividade encontrada para o extrato, é importante conhecer a sua composição. Ensaios feitos por HPLC a este extracto demostraram que este é constituído principalmente de compostos fenólicos tais como o ácido rosmarínico, que é o composto maioritário, o ácido cafeico e o ácido clorogénico. Sendo o ácido rosmarínico o constituinte 
published studies that, although carried out under different experimental conditions, also demonstrated a XO inhibitory activity for rosmarinic acid (20). In fact, previous studies mention that rosmarinic acid inhibits $\mathrm{XO}$ by a competitive mode of inhibition (20).

In addition to rosmarinic acid, $P$. saccatus extract also contains caffeic and chlorogenic acids in its composition, although these are present in much lower amounts. The effect of these compounds on the XO activity was previously evaluated by other authors. Huo et al (20), using in vitro assays, have shown that caffeic acid inhibits XO activity. However, this compound showed a higher $\mathrm{IC}_{50}$ value than that of rosmarinic acid. Wang et al (21), using different in vitro experimental conditions, demonstrated that chlorogenic acid is also capable of inhibiting XO. The study also demonstrated that chlorogenic acid has a lower $\mathrm{IC}_{50}$ than caffeic acid. The activities of the three main constituents of $P$. saccatus extract are therefore contributing to the global XO inhibitory activity observed for the extract. In addition, previous studies have demonstrated that these polyphenols have antioxidant (22) and anti-inflammatory (23) properties. This may have additional advantages in the case of a possible use of $P$. saccatus extract in gout treatment.

The results of this study suggest that $P$. saccatus extract and its major constituent should continue to be studied in cell-based experiments and in in vivo models in order to explore their potential as uric acid-lowering agents for the treatment of gout.

\section{Acknoeledgments}

João G. Costa acknowledges his Grant PADDIC 2016 awarded by ALIES / CBIOS / ULHT. The authors thank Professor MF Simões for the donation of the plant used in this study.

\section{Conflict of Interests}

The authors declare that there are no financial and/or personal relationships that could be viewed as presenting a potential conflict of interests. maioritário, avaliou-se o seu efeito sobre a atividade da enzima XO. Verificou-se que o ácido rosmarínico tem a capacidade de inibir eficazmente esta enzima. Este resultado está de acordo com estudos anteriormente publicados que, embora realizados em condições experimentais diferentes, também demonstraram uma atividade inibitória da XO para o ácido rosmarínico (20). De fato, estudos anteriores referem que o ácido rosmarínico exerce uma ação inibitória da XO, sendo esta inibição do tipo competitivo (20).

Para além de ácido rosmarínico, o extrato de $P$. saccatus tem também ácido cafeico e clorogénico na sua composição, apesar destes estarem presentes em quantidades muito inferiores. A ação destes compostos sobre a XO também já foi previamente avaliada por outros autores. Huo et al (20), através de ensaios in vitro, demonstraram que o ácido cafeico apresenta atividade inibitória sobre a XO. No entanto, este apresentou um $\mathrm{IC}_{50}$ superior ao do ácido rosmarínico. Wang et al (21), em diferentes condições experimentais, demonstraram que o ácido clorogénico também tem capacidade de inibir a $\mathrm{XO}$ in vitro. $\mathrm{O}$ estudo ainda demonstrou que o ácido clorogénico apresenta $\mathrm{IC}_{50}$ inferior ao do ácido cafeico. A atividade dos três constituintes principais do extrato de $P$. saccatus sobre a enzima $\mathrm{XO}$ contribuem assim para a atividade global observada para o extrato. Para além disso, estudos anteriores demonstraram que estes polifenois possuem ainda propriedades antioxidantes (22) e anti-inflamatórias (23), o que poderá trazer vantagens adicionais numa possível aplicação terapêutica do extrato de $P$. saccatus num contexto de gota.

Os resultados obtidos neste trabalho sugerem que o extrato de $P$. saccatus, bem como os seus constituintes principais, deverão continuar a ser estudados em modelos celulares e in vivo, de modo a explorar as suas potencialidades na terapêutica hipouricemiante da gota.

\section{Agradecimentos}

João G. Costa agradece a bolsa PADDIC 2016 atribuída pelas instituições ALIES / CBIOS / ULHT. Os autores agradecem à Professora MF Simões pela doação da planta utilizada neste estudo.

\section{Conflito de Interesses}

Os autores declaram não existir qualquer relação pessoal ou financeira que possa ser entendida como representando um potencial conflito de interesses. 


\section{References/ Referências}

1. Saccomano SJ, Ferrara LR. Treatment and prevention of gout. The Nurse practitioner. 2015;40(8):24-30.

2. Miguel C, Mediavilla MJ. [Current management of gout]. Acta medica portuguesa. 2011;24(5):791-8

3. Klippel JH and Dieppe PA. Rheumatology. 2nd ed. London, United Kingdom: Mosby, Elsevier Health Science; 1998.

4. Kim KY, Ralph Schumacher H, Hunsche E, Wertheimer AI, Kong SX. A literature review of the epidemiology and treatment of acute gout. Clinical therapeutics. 2003;25(6):1593617.

5. Choi HK, Mount DB, Reginato AM, American College of P, American Physiological S. Pathogenesis of gout. Annals of internal medicine. 2005;143(7):499-516.

6. Khanna D, Fitzgerald JD, Khanna PP, Bae S, Singh MK, Neogi T, et al. 2012 American College of Rheumatology guidelines for management of gout. Part 1: systematic nonpharmacologic and pharmacologic therapeutic approaches to hyperuricemia. Arthritis care \& research. 2012;64(10):1431-46.

7. Zhang W, Doherty M, Bardin T, Pascual E, Barskova V, Conaghan P, et al. EULAR evidence based recommendations for gout. Part II: Management. Report of a task force of the EULAR Standing Committee for International Clinical Studies Including Therapeutics (ESCISIT). Annals of the rheumatic diseases. 2006;65(10):1312-24.

8. Burns CM, Wortmann RL. Gout therapeutics: new drugs for an old disease. Lancet. 2011;377(9760):165-77.

9. Imboden J, Hellmann D and Stone J. Current rheumatology diagnosis \& treatment. 2nd ed. New York:Lange Medical Books/McGrawHill; 2007.

10. Infarmed - Autoridade Nacional do Medicamento e Produtos de Saúde, IP. Resumo das Características do Medicamento - Zurim (alopurinol) $300 \mathrm{mg}$. [18-01-2013].
11. Hainer BL, Matheson E, Wilkes RT. Diagnosis, treatment, and prevention of gout. American family physician. 2014;90(12):831-6.

12. EMA - European Medicines Agency. Resumo das Características do Medicamento - Adenuric (febuxostate) $80 \mathrm{mg}$. [05-022016].

13. Van Jaarsveld E. The Southern African Plectranthus. South Africa: Fernwood Press; 2006.

14. Lukhoba CW, Simmonds MS, Paton AJ. Plectranthus: a review of ethnobotanical uses. Journal of ethnopharmacology. 2006;103(1):1-24.

15. Rijo P, Duarte A, Francisco AP, SemedoLemsaddek T, Simoes MF. In vitro antimicrobial activity of royleanone derivatives against Gram-positive bacterial pathogens. Phytotherapy research. 2014;28(1):76-81.

16. Burmistrova O, Perdomo J, Simoes MF, Rijo P, Quintana J, Estevez F. The abietane diterpenoid parvifloron D from Plectranthus ecklonii is a potent apoptotic inducer in human leukemia cells. Phytomedicine: international journal of phytotherapy and phytopharmacology. 2015;22(11):1009-16.

17. Rijo P, Matias D, Fernandes AS, Simoes MF, Nicolai M, Reis CP. Antimicrobial Plant Extracts Encapsulated into Polymeric Beads for Potential Application on the Skin. Polymers. 2014;6(2):479-90.

18. Rijo P, Fale PL, Serralheiro ML, Simoes MF, Gomes A, Reis C. Optimization of medicinal plant extraction methods and their encapsulation through extrusion technology. Measurement. 2014;58:249-55.
19. Fernandes AS, Gaspar J, Cabral MF, Caneiras C, Guedes R, Rueff J, et al. Macrocyclic copper(II) complexes: superoxide scavenging activity, structural studies and cytotoxicity evaluation. Journal of inorganic biochemistry. 2007;101(5):849-58.

20. Huo LN, Wang W, Zhang CY, Shi HB, Liu Y, Liu XH, et al. Bioassay-Guided Isolation and Identification of Xanthine Oxidase Inhibitory Constituents from the Leaves of Perilla frutescens. Molecules. 2015;20(10):1784859.

21. Wang SH, Chen CS, Huang SH, Yu SH, Lai ZY, Huang ST, et al. Hydrophilic ester-bearing chlorogenic acid binds to a novel domain to inhibit xanthine oxidase. Planta medica. 2009;75(11):1237-40.

22. Sevgi K, Tepe B, Sarikurkcu C. Antioxidant and DNA damage protection potentials of selected phenolic acids. Food and Chemical Toxicology. 2015;77:12-21.

23. Gamaro GD, Suyenaga E, Borsoi M, Lermen J, Pereira P, Ardenghi P. Effect of Rosmarinic and Caffeic Acids on Inflammatory and Nociception Process in Rats. ISRN Pharmacology. 2011; 2011:451682. 